展望

\author{
鐜児言語指導法の一考察 \\ …アメリカ・日本・台湾の手話法を中心としてー
}

林

宝貴

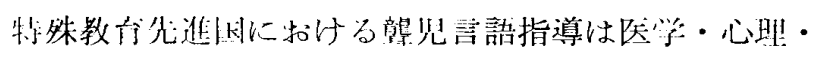
教育・工学など諸科学の発達の影響下で、口話法・聴能

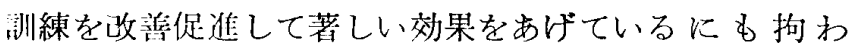

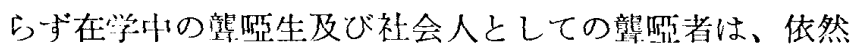
手話を交信の主な手段・又は補助手段として偏重してい る。最近特殊教育先進国の教育・心理学界の学者達も手 話の存在価值を見直し再評価しようといら傾向があり、 僅かながらも、それに関する実験調查の報告が出ている 現状にかんがみ、手話を言語指導上の補助手段として位 置づけ、より合理的な手話の整理・研究を行ならための 先行調查研究として、アメリカ・日本・中華民国（以下 台湾と省略する）の手話法について比較研究を試みた い。

\section{1. 韭教育機関の創設と背景}

(1) 世界の襲教育の起源について：世界で驡教育が 最も早く起ったのは、ヨーロッパで、スペインの宗教師 ポンセ (Pedro Ponce de Leon) が1555 年スペイン北 部のヴァラドリッド市に竩学院を創設して襲者に発音、 読毒・書き言葉を教えたときに始まる。彼は指文字と手 まねを教育の補助手段とした。ポンセの継承者ボネート

(Juan Paulo Bonet) は、ポンセの残した輝かしい成 功の記録に基づいて「アルファベット文字の簡素化及び 驡涇者に話し方を教える技術」といら本を1620年に出版 した。これが世界最初の壟言語指導の著述であり、その

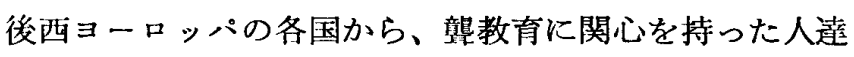
がスペインへ見学に行き、この本を持り帰り、自国の言 語指導の教材として使用した。その後、イギリス、スイ ス、オランダ、フランス、ドイッなどの备国がスペイン の教育法を導入し、学校教育は軌道に乗り、教育方法は 手話法と口話法が対立する局面から次第に口話法を統一 する方向に進み、二十世紀に入ってからは、就教育の研 究が益々進み、残存聴力や失聴年令、または既有言語能 力、知能程度などに大きな個人差があることが分かった
ため、これに適心した教育法の実践が痛感されるに至 った。就学に関する法規、学校の組織、教育課程、修業 年限、学級編成、教員養成などもこれ伴い漸次発展充 帮してきたことは言うまでもない。科学の発展、熊者に もたらした幸福は少なくない。

(2) アメリカの龍教育の起源之変革について：1776年 稩喼者教育の必要を説く啓蒙家の活動が始まるまでは、 鱀教育有史以前と見なければならないであろう。1817年

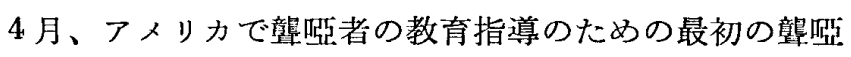
学校と見られるコネチカットアサイラムが創設されるこ とになったのは、ハートフォード校がギヤローデットと シカールの門弟クラークの二人により、フランス方式を 取り入れ、手話、指文字、書き言葉を結合した無音法教 育を実施したからである。1810年から南北戦争まで、多 くの学校が口話法を採用しないで、もっばら手話法とス ピーチ、読唇を併用した。コンバアイン方法 (Combined Method）を発達させていたことを考えると、産業 革命期は教育方法の過渡期であったと見られる。1843年 ホレス・マンとハウは、ドイッの学校を見学し、ヒルを 指導者と戴くドイッ法の長所を認め、州国後報告してい る。1867年10月ノーサンプトンに開設されたクラークア サイラムは口話法を教育した最初の学校である。各校と も初めは手話、指文字が基礎で、スピーチ、読唇は補助 とされてきたが、19世紀末頃から、口話法の世界的な発 展にしたがい、読唇、スピーチにより重点が移されるこ とになった。第一次大戦中ピントナ羍により壟児の知能 検查の開発、人格評価、性格研究などが行なわれるよう

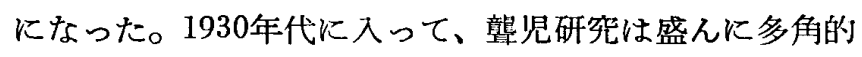
な発展を遂げ、教育内容と方法の充実発展も多大な成果 を収めている。特に龔児、難聴児の残存能力の訓練、聴 音法、聴話法の開発面に大きな努力が注がれている。

(3) 日本の暗教育の起源と言語教育の变遷について: 日本に括ける最初の驡学校教育としては、明治11年 (18 78年) に京都盲啞院が、次いで明治13年に東京の楽善会 


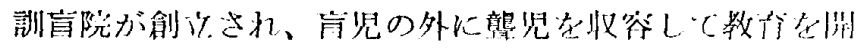

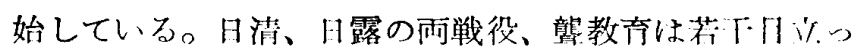
た進步を遂げて、明治42年には、富学校上驡听学校が分

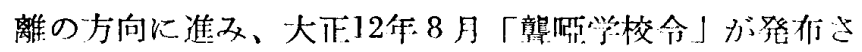
れてから、冝驡の分離が制度化された。ことに第…次人 戦後に招いて、「学校教育法」が制定され、昭租23年㳯 教育が義務教有に編入されると其に、两期的な進少を遂 げるに至った。炤和22作「受校教育法」がけ法制定され

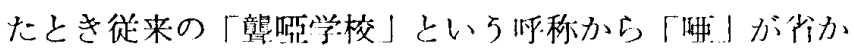

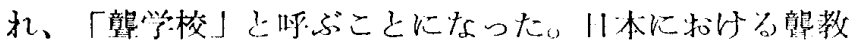

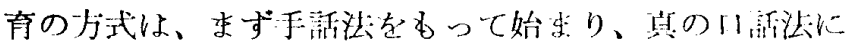

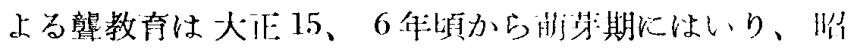

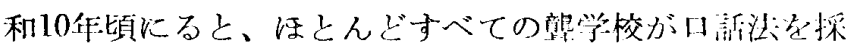

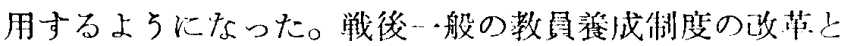

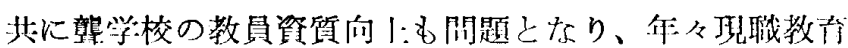
の実施、及び研篎集などが工夫されてきた。

(4) 台湾の龍教育の起源乞発展について：台湾の最初 の身体障害教育はキリスト教ブロテスタント派（Protestant) の宣教師ウイリアム・カンペル（Willan Cam pbell）によって始められている。彼は1890年台湾の南 部「台南」の教会内に「訓韾堂」を設けて、盲人に聖書 点字、手芸を教えた。1916年に喂生部が増設され、盲啊 児共学の「私立台南盲喂学校」となった。1917年日本人 の医阨木村謹吾氏が台湾の北部「台北」に「木村肓睡教 育所」を設立したが、2年後それは「私立台北盲盟学 校」となった。これは、台湾が第二次大戦後まで、日本 の領有地として行なってきた㽬教青の状態であった。第 二次大戦後、台湾は中華民国の一省亡なり、2つの盲哂

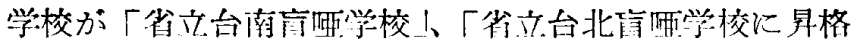

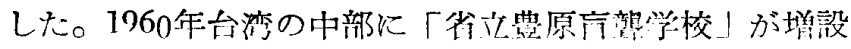
され、1968年盲龍学校が分離設置とたったさいに、「省 台台中辟聘学校」と改名して、企部部生を收容すること になった。盲生は「台南盲眮兴校!の狊生と合作し、新

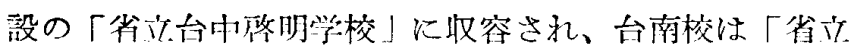
台南啓聰学校」と改称した全部螅生を収容した。台北校 は来年から盲龍分離設置の第一歩を踏み出すということ であるが、現在まで、台湾に打ける驡学校はまだ三校に 過ぎない状熊である。教育方法は口話法・手話法を併用 したものが主体となっているが、漸次口話法及び聴淤法

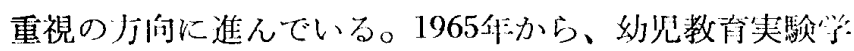
級が設けられて口話法教育を行なって扣り、1967 㫦か 5、口話教育実験区を設置し、手話禁止の純口話法を採 用しているが、かなり効果があがっているようである。

\section{2. 言語指導法理論の歴史的考察}

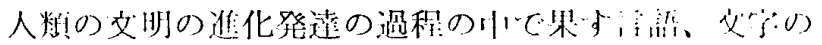

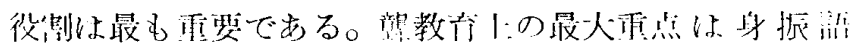

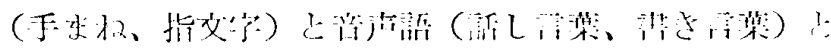

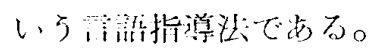

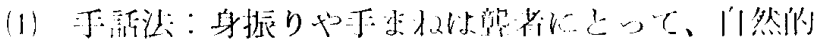

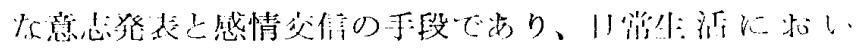

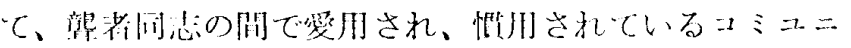

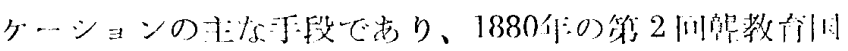

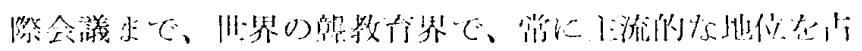
ぬてをた。

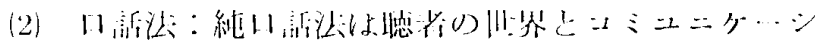

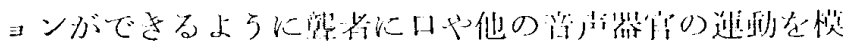

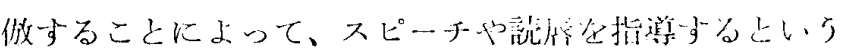

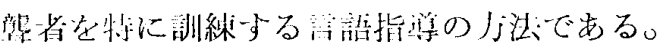

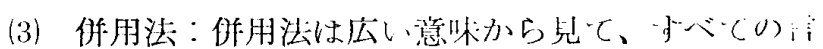

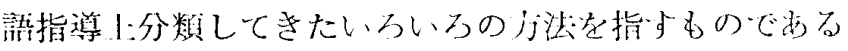

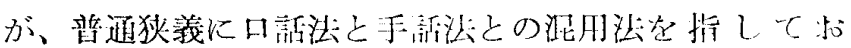

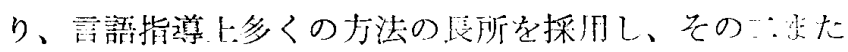

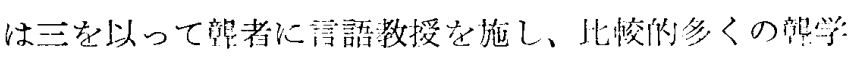
校（特にその高学年）に持いて、現実に多く見受けられ る方法である。

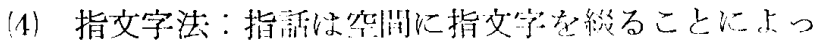

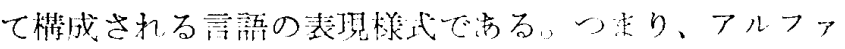

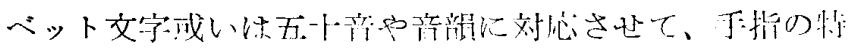
定の位置、郮位、形熊を定めたものであって、これを过! 続的に緅ることにより交信するものである。

(5)書き言葉としての文字法：普通一般健聴者にも文字:

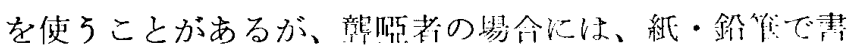
き言葉によって会睭面でのコミコニケーションの手段と するもので、筆談・文訢立哦と呵ばれる。

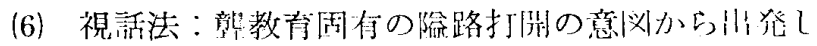

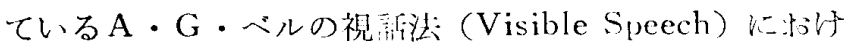

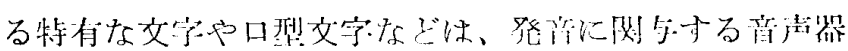
官を略画的に示すように工头し、それによって発邽、発 厞の指導にも便利をはかっている。

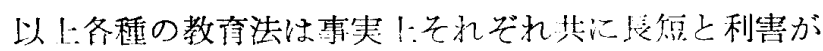
あり、限界があるため、それらの諸方法ですべてが無养

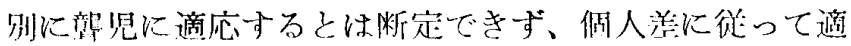

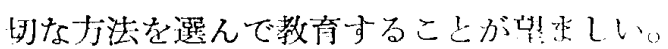

\section{3. 最近における各国の実験調查に関する報告}

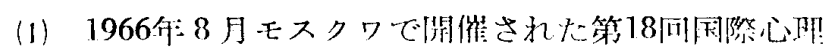

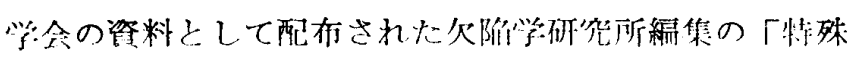

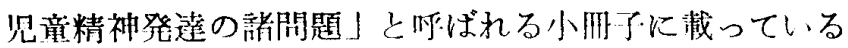




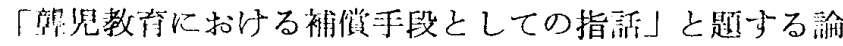
文には、「久陷学研究訢が行なった研究の結果として

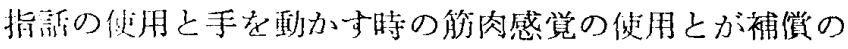
西要な要䒺であることが溞調されている。それには指

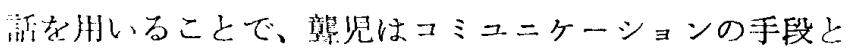
しての棓語を非常に早く垣得し、しか子それに成功与 る。学校で勉強する最初の日から子俱避は箱といら于 段の妙けにより、お互いにコミュニケーションを始め

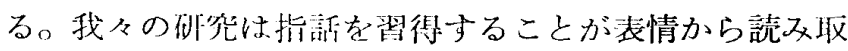
ることをいささかる妨げない事実を立颜した。指話の拉

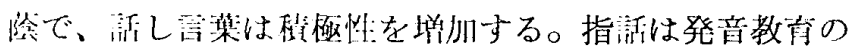

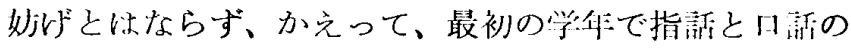

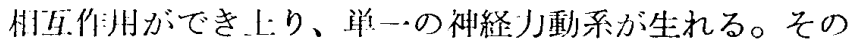

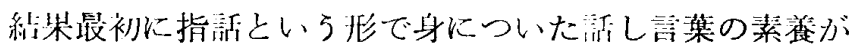

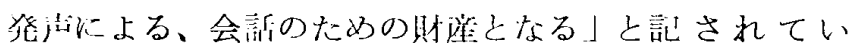

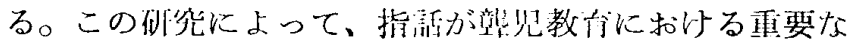

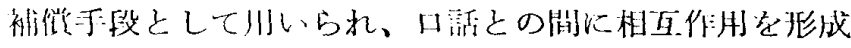

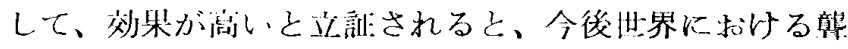

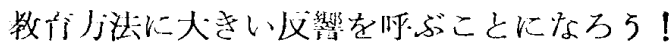

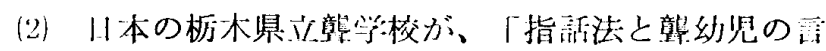

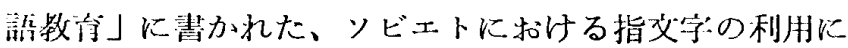

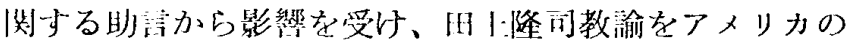

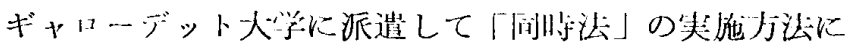

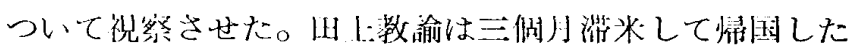
後、ギャローデット大学で契施している「间时法」を内

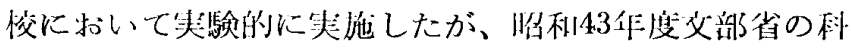

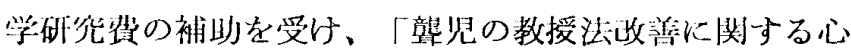
明学的砄笔」についての資料学作成した。3力年の実験

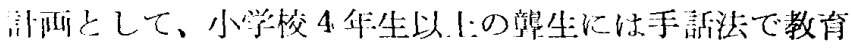

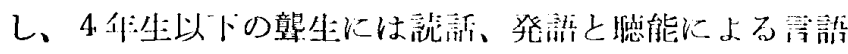
指道に全少を沚いでいる。

（3）アメリカの Roger G. Barker 《次の上うに指

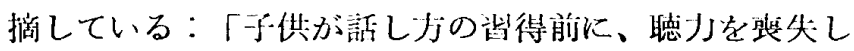
た垶合は、スピーチの訓練と読唇がとても難かしく、5 まく䛨唇を筸得することが不可能で、またらまく話せな い第合は口話交信の㥜得を強制的に教えると、結局着恥 心を起こしたり、フランストレションになったりして、 パーソナリティの閆題を引き起こさせることになる。そ れよりもむしろ彼らに他の表示や交信、㗲記や手話の方 法を発達させた方が有登である。若し、龔児が難かしい 口話、交信の前に、早期にサインによる自然䨩語が助髟 されることになれば、㰍児にサインで話すことができ、 自身の言韽で自身の経験を体験することによって、彼ら 白身に関する実際の経験がより広いものとなる。万一期

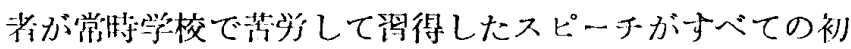

対面の人にほとんど理解されず、彼の職場です実際の役 には立たないと悟ったとき、彼らのパーソナリティに何 が起きるであろう？ 即ち一灂の劣等感、失望、落胆、 退樱以外飞はあり得ない!」

(4) 1966年フメリカのピッパーフ大学の特殊教育とリ ハビリテーション教育学科が発表した「輒児の言語発達 に扮ける等期手話法の影響」に関する研究報告には、次 のように述べられている：「この二、三世紀いらい、稩教

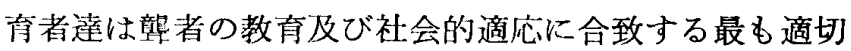
々思われる各種の教育方法を試みてきたが、研究問題の 㤈はやはり内活法と、手話法が㰍者にとってどちらが 付陉であるかといらことである。欢うの諭者達はみんな

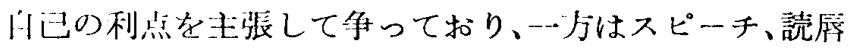
と聴能訓練に上って熋者の欠陷を軽減しらると主張し、

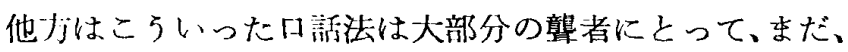

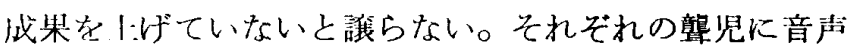

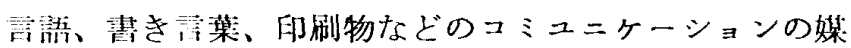
介を通じて、交信手段を尔えることができる。若し早期 の丁語父信がこの月的を妨げると、マイナスの影響を与 えることになり、また反対に、若し早期の手話交辦がこ の川的の掉成を促進させると、プラスの影響を与えるこ とになる。調查の絬果、5つの結論が玔された：1. 臂

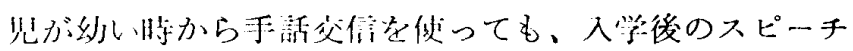

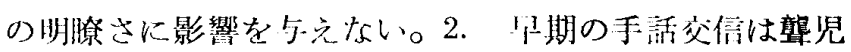

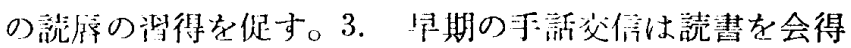

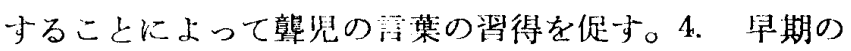

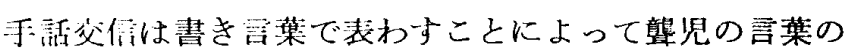
谓得を促進させる。5. 早期の手話交信は襲坚の社会的 心阯的な淔江打ける発達化、マイナスの影響を与えない のみならず、かえって、プラスの影響を与える叮能性が ある。聞兄る子供は音声言語といら父倍体系を早い時期 飞発展させると、後目の等声交信生活で技術的に確かに 役に立つが大多数の襲愳に早期の口話訓練を施すことが 梢益であるかどうかは疑關である。」この報告によって、 犝児の两親が $1 、 2$ 才の幼ない犝児に手話交信を導入す るより、奖为することができる。子供が学校に入った後 む言葉の発達を妨げる垫れがないのみならず、幾分有利 な点が期待できる。

(5) 同1966年スコットランドに打けるェテンバーフ・ ドンナルドソン曂学校 (Edin burgh Donaldson's School for the Deaf) の心理学者が行なった「重度の熊 成人の手話交信に対する口話法の関係」についての研究 で、次のように指摘している：「スピーチ、読唇と知能 に関する 3 つの標集検査において、55名の憼卒業生に対 しスピーチ、読示及び手話交信についての評価を別々に 
与えて、口話法と手話法の間の矛盾関係がどこまで顕著 であるかどらかを実験した。従来、最も䈌しい口話学校 に执いては重度の韵者が指文字或いは手まねを用いてコ ミュニケーションすることは許されていない。その理由 は、手話法の発達は読唇とスピーチの口話法の成辰を妨 害するからであるとされている。口話主義が現代教育方 法上に支配的な地位を占めているにも拘わらず、この実 験の結果によると71\%以上の卒業生はやはり指文字で流 暢に交信し、25\%の人だけが読唇をを用いて打り、十分 に流暢明瞭なスピーチで話せる人は僅かに $7 \%$ に過ぎな い。」この研究の報告にも「手話がスピーチと読唇の発 達を妨害し、またに矛盾を起こさせる」という一般人の 意見とはかなり異なった結果が出ている。

(6) 1964 年アメリカのスチーブンソン (Steven son) は、驡者である両親の子供と龍者でない再親の子供の間 の学業成績を比較し、次のよ5に発表している：「134名 の前者群の内に、14人だけが学業成績不良である。つま り、90\%の襲者を両親にもつ子の方が成績優良と見られ た。また、90\%の内の $38 \%$ は大学在学中の成績も良いが これに反して、聾者でない親の子供の方は僅か $9 \%$ だけ が大学時代の成績が良いという結果が出ている。」

(7) 1960 年フメリカのブリル（Brill）は「(1) 45 人の 龍親を持った壟児、(2)同数の正常の両親と襲兄弟がいる

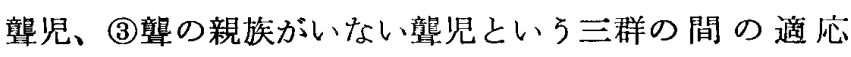
性を比較して、三群の性別、年令、I Q が等しく、全体 としては著しい相違が見られなかったが、男の子のみを 比較する場合、差異が顕著に出ており、(1)群の方は良く 適応している。(2)群と(3)群はより極端な成績が見られる が、(3)群の成績があまり極端でないと示している」とい う結論を下している。

(8) 1961年クイグレー (Quigley) とフリジナ（Frisina）達は寄宿学校の通学生と奇宿生のスピーチ能少を 比較し、次の上 5 亿報告している：「120人の通学生の 内の16人は聾である親をもつ。この16人を壟でない親を 持つ䆍児と比べると、スピーチの能力が遙かに低いが、 彼らの指緅りと語彙の程度が著しく高い。これは手話法 使用の結果が語鲁の発達に役立ったからである。読話能 う晑では、両群の間の差買が見られない」。

(9) 1968年メードゥ (Meadow) が59人のカリフォー ニフ䚒学校の醅生について知能、社会性、コミュニケー ション能力（書く、話す、装わす及び言葉の受け入れな どの能す）の調査研究を行なった結果、次のように報告

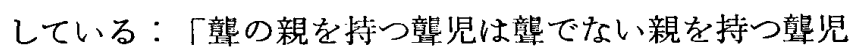
よりも、知能と社会適応性が高い。読話と発語の審査で は、はっきりした違いが現われていないが、書記語、指
経りの受理や表現能力、手話の使用能力面の比較につい ては、㢣の親を持つ㢣児の方が著しく高い水準に達して いる」。この調查結果は、従来教育専門家が主張した犝 児の親達による手話交信の使用は望ましくない」という 勧告に有利な証拠を与えず、むしろ、調查対象となった 手話交信で䏍てられた㜔児たちが、それぞれの測定に拉 いて、いずれもより高いレベルの得点を得たという事実 を紹介している。すなわち、协い時から口話と手話を結 びつけて教えられた襲児達はより良いコミュニケーショ ンのカを得ている事実が立証されているのである。

(10) 以上各専門家の実験報告の中で、驡闭親を持った

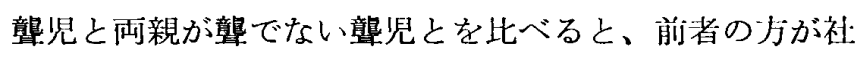
会的経験が著しく優れていると認められたのであるが、 その理由は：1. 壟両親を持った壟児は聴覚障害を持っ ている両親からょり多くのいたわりと同情を受けて、情 緒的に安定している。2. 両親も壟者である大多数の龍 児は、極めて幼少の侍代からすでにコミュニケーション の手段を留得している。それは勿論彼らの両親と手話を

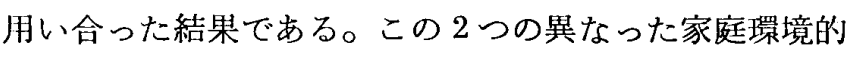

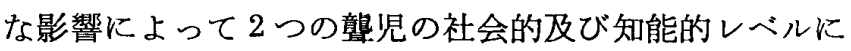
差が生じる。他面、大多数の襲児の健聴者の親たちは 「幼い龍児が手話をコミュニケーションとして用いる ことは好ましくない!」といら見解を持っている。その 理由は：「手話を先に教えることは後日のスピーチと読 話の学習や発達に役立つことは稀であるからだ」として いる。しかし、ある社会学者、例究ばアメリカのフオル ス（Furth）は、逆に「暗児が幼ない時期から手話を用 いることは、スピーチの望得に対して有益である」と主 涱している。

(11) イギリスのレウイス委員会 (Lewis Committee) が手話法の価值と襲教育に拈ける地位を検討するため、 全国 9 つの機関の 169 人による心理学者、精神病学者、期 者関係の福祉職員ならびに壟教育に独特な見解と認識を むつ大学の研究者、教育者、臨床実験者 (その中の 3 人 はアメリカから招待した参加者）によって構成された廆 大な委員会がアンケートをつくって全国の部学校や関倸 のある機関の責任者に送り、その返事をまとめて公表し た報告がある。それはイングランド、ウイルス、スコッ トランド 3 地区の60個所の学校及び98個の団体から出さ れ问答を集成したもので、報告の題目は「口話法の教育 的な利益」と「手話法及び併用法の教育的な利益」であ る。その調查結果は「手話法がこれから広い路を開拓 し、䆍学校に採用されて普及する」と期待している人を 失望させるものであるかもしれないが、次の、2、3 の勧 告内容から見れば、やはり手話法の存在を肯定している 
のである。例えば：第 2 項に「全㲃でない、即ち残存聴 力がある壟生は手話法の採用を必要としないが、重度の 難㯖児または全韵児の場合には、手話使用禁止の制限を 除去してよいかもしれない......」とあり、第4 項には手 話法がどんな条件、どんな環境の下で、聾児教育の改善 にどんな影響を与えるかとい5点について決定的な研究 を行なうべきである」とあり、第 8 項(a)には「こういっ た調查研究は口話法と手話法の併用する刘果、（例党ば ソビェトク法、デンマークの手口共用法 “Hand-Mouth

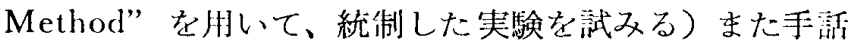
泣と山話法の実施するプロセス（読話能力を包含する因 奖、手指法と読話訓練の交沙、片手や両手の 指経りな ぞ)を核心研究を進めるべきである」とあり、また第 10 项にはある子供に綜合併用法を行なっている等校は、必 ず全般的に細かい配慮を忘れてはならない」とあり、 さらに第13項には学校では、䒾児のそれぞれの需要に応 じて、于活法を口話法の補助手段として適当に教兄れば 是いし、宕しも純口棓法で十分に進歩が見られる子供の 埸介には、純口話法に上る教育を積極的に考慮しなけれ ばならない」と述べている。以上のレウイス委員会の排

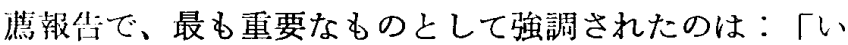
ずれの調查機関から来る意見でる、口話法だけではすべ ての龍児に対する最適な教育力法であるとは認められな

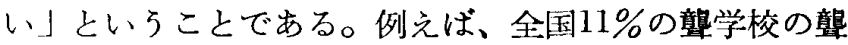
生がつ权に指話を用いて打り、僅か $4 \%$ \%だけの龍生が乎 まねを使用している。この割合は1964年アメリカのバビ ッヂ委員会 (Babbidge Committee) の調查が、全国公 沃の繁微学校の熋生の $80 \%$ が乎指法を使用していると報 售しているのに比較すると、かなり少ないが、事実、若
以上各国の心理、教育、社会科学者などの調査研究報 告を綜合すると、手指法は壟児の読話と発音訓練を妨げ ず、かえって、知能と社会適応性を高め、語彙の認識力 を強化して扣り、口話法の補助手段として教育上使用す るのは良いことであるという結論が出ており、また、教 育現場を見ても、多くの生徒が毎日手話を使用して打 り、それを使わずにいることは無理であることが分か る。また日本、アメリカ、台湾 3 国の聾教育方法の進少 発展過程から見ても、いずれも手話法から、併用法を経 て、口話法へ進展するという共通点が窺える。台湾の臂 教育は戦前、日本の特殊教育の影響を受けており、さら に日本の龍教育はフメリカに留学してべルの視話法を学 んだ伊沢修二と欧米の壟教育を視察した川本宇之介及び 口話法推進に大きな役割を果たしたライシャワー博士夫 妻による日本㰍話学校の開設など、アメリカの影響が日 本の襲教育を大きく転換させ前進させている。アメリカ の手話法はフランスから輸入され、その後発展した口話 法もドイッの口話主義の影響を受けて括り、アメリカの 言語指導法は実際には世界驡教育方法の集的であると言 える。この辺で台湾が最も密切で、親善な二国一日本と フメリカと歷史的、交化的に交流した結果を考えなが ら、三国の壟啞者相互間のコミュニケーション方法とし ての手話の同異点を比較分析することにする。

\section{4. 各国における手話法技術の比較}

アメリカ、日本、台湾に和ける日常生活中よく使って いる手話の代表的なるのを選 んで、名詞、動詞、形容 詞、副詞、前置詞、疑問詞などの品詞別に比較を試みた 結果、その同異率は次の通りである：

\begin{tabular}{|c|c|c|c|}
\hline 比 較 国 別 & 調べた手話数 & 同じ個 数と此㳯 & 違 5 個 数 と比 率 \\
\hline 台湾と日本 & 769 個 & 全く岡じもの 360 個：46.9\% & $\begin{array}{lr}\text { 稍々違 } 5 \text { も } 409 \text { 個 } & 51.1 \% \\
\text { 全然違 } 5 \text { もの } 307 \text { 個 } \quad 40 \%\end{array}$ \\
\hline 台游とアメリカ & $\begin{array}{l}\text { 全体の手話 538個 } \\
\text { 動詞だけ } 143 \text { 個 }\end{array}$ & $\begin{array}{l}\text { 類似 } 91 \text { 個 } 15.6 \% \\
\text { 類似 } 39 \text { 個 } 27.3 \%\end{array}$ & $\begin{array}{ll}\text { 全然違 } 5 \text { もの } 447 \text { 個 } & 84.4 \% \\
\text { 全然違 } 5 \text { むの } 104 \text { 個 } & 72.7 \%\end{array}$ \\
\hline
\end{tabular}

テの学校でも手話法を採用している。その外、国立暜教 員養生学院の執行委員が口部法のみを推奖し、頝固に和

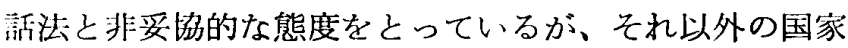
視察官、壟人関係の福祉職員、汇立戅人機構及びスコッ トランドの襲人協会、英国盲竩協会、難聴者協会、臨床 実験の委員会などは、みんな手話と指文字を知恵遅れと 口話成績不良の犝児に教光ることに有益であり、読話と 発語訓練の補助手段として使うことが望京しいと認めて いる。
以トの割合から見ると、日本と台湾の手まねは似たり 寄ったりで、違いがあれば、それは両手と片手の違いと か、大動作と小動作の差とかだけである。769 個の日常 生活中でよく使われている手ま权を調べた結果は、360 個が同じであり、409個が少しだけの違いである。いわ ば、46.9\%が全く同じであり、53.1\%の違いの中で、全 く違い全然通じ合わないるのは約 $40 \%$ だけと言える。こ の割合から見れば、日本と台湾の手ま视が半分以上類似 していることが分かる。これは、第二次大戦前、日本が 
台湾を領有していた時残った手まねが今も台湾に招いて 依然として使用されて和り、その余は、国民政府の接収 後日本語と全く違った中国語の表現が付け加えられ、ま た時間と環境が逐漸的に変遷するなかで、手話語もそれ ぞれ、変化してきたことを意味している。こうした日本 と台湾の手ま权に見られる共通点は歴史と文化の産物と して見ることができよ5！

ところがアメリカの手ま权は、日本や台湾と相似す るものは少なく、違っているるのが多い。また、アメリ カの手まねの中には、沢山の表わしにくい表現を単珸の 一番目の英交字の指交字形で表わす場 合が多い。例兄 ば、“East”を "E” の指文字で “Paper”を „P”の指 交字で “Sorry”を"S” の指文字で表わすことである。 538 個の日常手話語を調べた結果、僅かに91 倜が同じで あり、447 個が異なっていることを判明した。その割合 は、15.6\%が同じで、84.4\%が全く違らことを示した。 この大きな差異の中で、ただ動詞の面でや〉高い類似率 が見られる。即ら、合計 538 個の中には、143 個の動詞 がむり、その動詞中で同じものは39個、つまり $27.3 \%$ と い5百分比を示しており、全体の $15.6 \%$ が同じとい5比 率に比較すれば、かなり高いと管える。これは、動詞の 手まねはその動作の状態と姿をそのま々に真似て表わす からである。そして、東洋と西洋との文化、宗教、風 俗、習慣上のいろいろな要素が英語の表現とか、文の構 造や文法、語順とかで、中国語や日本語との多くの相異 点をつくり出しているのである。例兑ば、英語の中に は、沢山の宗教的な手まね（教会、聖書、大司教、洗礼、 天国などが）あるか、日本や台浮の手まねには、これら のものはあまり見られない。また英語では“I, me, my， myself, you, your, yours, yourself, youselves" な どの主格、受格、所有格の区別がはっきり分けられてい るが、中国語や日本語にはこれらの区別が助詞の助けを 借りなければならないので、フメリカの手まねは、日 本や台湾に似ているものは、たやすく模倣できる動詞 （例觉ば食べる、飲む、漫る、開く、閉める、愛する、 泣く、コピーする、立つ、坐る、選ぶ、程 5、書く、 運転する、顔を洗 5、洗濯する、会 万、飛ぶ、目を賞 す、離れる、聞く、なめる、思うなど）或いは大きな 特徵を持った名詞例之ば動物の猫、牛、鳥、鴨など。 普通名詞のこし、帽子、家、歯ブラシ、バナナ、えり、 冬、手まねなど。数字の一、二、三、四。抽象名詞 の天使、戦争、光明、権利、力、時間など、形容詞、 （例えば寒い、あかるい、暗い、軽い、重い、短い、 怖い、美しい、憎い、やわらかい、細い、太い、強いな ど）、副詞（例总ば up, down, there など）前置詞
(例えば around, to, into, behind, in front of, under など）あいさつの言葉（例えば goodbye, Hello など） といったいわば万国共通の原始的表現の手まねである。 この三国の手まねを相互比較した結果、「手話は世界共 通の言語であるが、その共通点はある一定限度に限られ ており、手話は世界的に統一されて扣らず、全般的に共 通するものであるとは言えない。英語のよ5に統一化さ れ、普及化されるまでには、まだ遠い道が残されてい る」といった結諭が下せるのではなからうか？

\section{5. 台湾における聴賞障害児の言語教育の実態}

第二次大戦後の台湾に扮ける犝教育言語指導法につい て述べると、靖学校は 3 校（台北盲腤学校、台中豊原啓 聰学校、台南啓聰学校) とす、多少の羑はあれ驡生に口 話法、手話法及び箻談を併用して指導している。純粋口 話法の実験的な試みは幼稚部の暗坚に限り、今迄10数年 といら短かい期間に、著しい効果を収めてはいるが、ま だ普及しているとは言えない。1969年夏期休层中台湾の 㢣生 175 人を対象に、各種教育方法についての意見調查 を行ない、次のような結果を得た。

1. あなたは_才男（女）性ですか？

年令 $13|14| 15|16| 17|18| 19|20| 21|22| 23|24| 25|26|$ 男 |女 合計

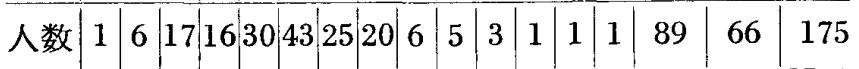

2.あなたは—部—年の学生ですか？

\begin{tabular}{cc|c|c|c|c|c|c}
\hline 学 & 年 & 初一男 & 初一女初二男 & 初二女 & 初三男初三女 \\
\hline 人 & 数 & 12 & 11 & 18 & 15 & 20 & 18 \\
\hline 学 & 年 & 高一男 & 高一女 & 高二男 & 高二女 & 高三男 & 高三女 \\
\hline 人 & 数 & 15 & 20 & 16 & 15 & 8 & 7 \\
\hline
\end{tabular}

3. 先生達が授業中に用いている教骨法はなんです か? (1)手話と口話に上る併用法 (2)純口話法 (3)純手話 法 (4)板書 (5)読唇 (6)指話法 (7)筆談

\begin{tabular}{lc|c|c|c|c|c|c}
\hline 項 & 目 & (1) & (2) & (3) & (4) & (5) & (6) \\
\hline 人 & 数 & 99 & 2 & 64 & 8 & 1 & 1 \\
\hline 百 分率 & 56.56 & 1,14 & 36.56 & 4.56 & 0.9 & 0.9 \\
\hline
\end{tabular}

教師達によって異なった方法で教えているようであ る。手まねができる教師は大体手話法を使用し、手まね ができない教師はほとんど黒板に字を書いて、説明して いる。台湾で指話法は全然使われていないので、この 2 人の回答者は、指話法を手話法の代わりであると思い違 
えたのであろう。

4. 上列(1)—(6)の方法の中で先生達がどの方法で教育 すれば最も望ましいですか？

\begin{tabular}{|c|c|c|c|c|c|c|c|}
\hline 項 目 & (1) & (2) & (3) & (4) & (5) & (5) & 無意見 \\
\hline 人 数 & 101 & 22 & 5 & 11 & 10 & 13 & 13 \\
\hline 百分率 & 57.71 & 12.56 & 2.85 & 6.28 & 5.71 & 7. 44 & 7. 44 \\
\hline
\end{tabular}

大体学年が高ければ高いほど、手話法で教育してもら いたいと希望する者が多い。理由は高学年に複雑な教科 内容では、読話法が聞き取りにくいからである。純口棓 法で教育することを望んでいる人は、大体話し言葉を多 少覚えた、5、6才以後に失聴した学生か、或いは低学 年に発音訓練を受けたとき成績が良かったものである。 無意見の学生には、男子が女子より多く、低学年者が高 学年者より多くなっている。

5. (1)一(6)項の方法で、日常生活に扔いて、最も有用 だと思われるのは、どれですか？

\begin{tabular}{cc|c|c|c|c|c|c|c}
\hline 項 & 目 & (1) & (2) & (3) & (4) & (5) & (6) & 無意見 \\
\hline 人 数 & 59 & 22 & 20 & 19 & 19 & 27 & 9 \\
\hline 百分率 & 33.71 & 12.57 & 11.42 & 10.85 & 10.85 & 15.42 & 5.18 \\
\hline
\end{tabular}

6. あなたは—万方法で、家族と話をしますか？

\begin{tabular}{cc|c|c|c|c|c|c|c}
\hline 項 & 目 & (1) & (2) & (3) & (4) & (5) & (6) & (7) \\
\hline 人 & 数 & 37 & 31 & 26 & 31 & 18 & 16 & 16 \\
\hline 百分率 & 21.17 & 17.71 & 14.85 & 17.71 & 10.28 & 9.14 & 9.14 \\
\hline
\end{tabular}

(4)項目之(7)項目の回答は合併してもよい。教室におい て、教師が黒板を利用して学生に説明する場合に用いる 交信手段は「板書」であるが、家で家族と交信する昜 合、黑板に代って、筆談をする鉛筆と紙で相互に意思を 伝達するのである。実際、この筆談こそ薛生達にとっ て、家族や社会の他の健聴者との重要な交信手段なので ある。

7.あなたは(1)一(7)方法の中で、どの方法で学校の先 生や友達と話しをしますか？

\begin{tabular}{cc|c|c|c|c|c|c|c}
\hline 項 & 目 & (1) & (2) & (3) & (4) & (5) & (6) & (7) \\
\hline 人 数 & 49 & 37 & 25 & 23 & 8 & 20 & 20 \\
\hline 百分率 & 28 & 21.14 & 14.24 & 13.11 & 4.57 & 11.42 & 11.42 \\
\hline
\end{tabular}

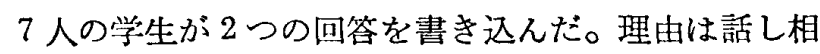

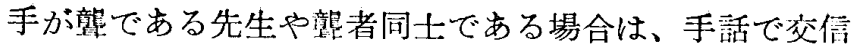
する。話し相手が手話のできない教帎の場合は、筆談や 口話（簡単な㝘葉ができる暜生にも）で交信するように なっている。

8. あなたはどの方法で社会の他の健聴者之話しをし ますか?

\begin{tabular}{c|c|c|c|c|c|c|c|c}
\hline 項 目 & (1) & (2) & (3) & (4) & (5) & (6) & (7) & 無意見 \\
\hline 人 数 & 28 & 46 & 18 & 30 & 9 & 20 & 20 & 4 \\
\hline 百分率 & 16 & 26.28 & 10.27 & 17.14 & 5.14 & 11.42 & 11.42 & 2.33
\end{tabular}

4人が製意見上書き込んでいるが、これは低年㬝では 男の方が女の方上りも多い。(4)項目之(7)項目の回答は合 併できる。理由はすでに第6關に述べたので、ここでは 省略する。

9. あなたの雨親は学校がどの方法で教育することを 望みますか?

\begin{tabular}{|c|c|c|c|c|c|c|c|}
\hline 項 & (1) & (2) & (2) & (4) & (5) & (6) & (1) \\
\hline 人 数 & 56 & 41 & 18 & 23 & 9 & 21 & 7 \\
\hline 百分率 & 32 & 23.47 & 10.28 & 13.14 & 5.11 & 12 & 4 \\
\hline
\end{tabular}

10. 上列の教育方法以外に、まだどんな良い方法があ ると思いますか？

この問いに出された多数の意見は口話法、読唇法、筆 談、作文などによる万法で、健聴者と交信する手段を有 効的に促進させて行くょ5と望んでいる。

以上の調查結果に次のような結論が出た：

1. 現在台湾の血生達は主として手話法と口話法の併 用で教えられている。

2. 半分以上の血生はやはり先生達に手話と口話で行 なう併用法で教えてもらいたいと望んでいる。

3. 日常生活に対する最る有用な方法としては、手話 と口話による併用法の割合がやや高くなっているが、そ の他、各種方法も同程度の重要性を認められている。

4. 睯生が家族と交信する方法には手話があるが、口 話と筆談も 2 番目の高い比率を占めている。

5. 学校生活に扰ける先生達と犝生達の間の交信方法 としては、手話と口話の併用方式が一番多い。

6. 社会生活に扣いて、健聴者とのコミュニケーショ ン手段としては、口話が最も多い。

7. 両親が学校に対して希望する教育方法としては、 手話と口話による併用法の外に、純口話法で教えること を最る望んでいる。

8. 蠪生達自身む健聴者と自由自在に交信できるよう 
希望しているので、教師達に有効な教育力法で全力を尽 して、彼らを教育することを願っている。るちろん、こ の日的を達成するためには、現在台湾の襲学校で用いら れている手話と日衙だけの湖州法では小分でなく、ロ 浯、誏原、筆談、作文、発音訓練、聴能訓練などのすべ てを邀宜聂り入れて行く必要がある。

9.この調相の対像になった壟生はすべて中兴生や高 校生であり、鄣教育を最低、5、6 年間受けているが、

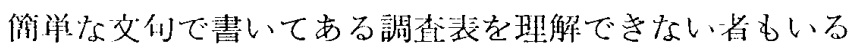
ので、先生達に赖んで、手末权で説时してもらったが、 末だ成しく答えることができないものもいた。李た、10

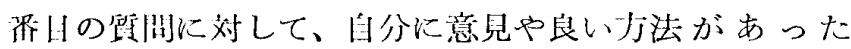
ら、畫いて下さいと求めたとき、多数の回答文の中には 流惕ではないるの、何を金いているのか分からないるの

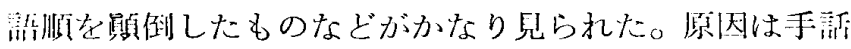

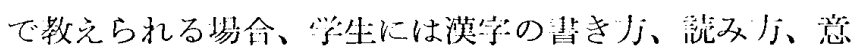

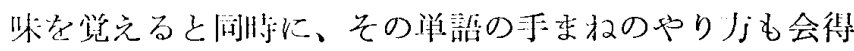
寸る必要があり、今度巵分が交章で表現与るさい、手东

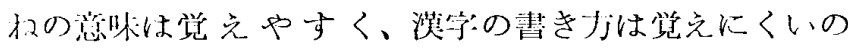

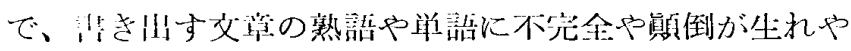

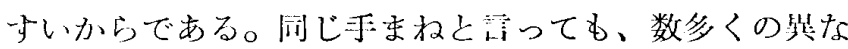

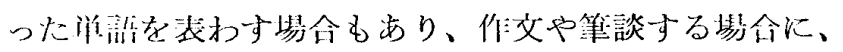
どセらの洋浯を州いるのが適甽かといらことは本当に敬 かしい間題となってくるのである。この䛊をりを回避す

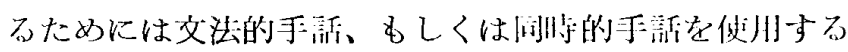
のがよいと考える。

次に台湾の現行手語の欠点を総括的に述べて見上ろ：

1. 于活の文構造が洇語の文法に合っていない：于 活の權文規则が貧弱であるため、怨意的で、個人臸が火 きい。例えば「列三比李四有鈛」（脹さんは李さんより む金持だ）という内容を手棓で表現してもらったとこ ろ、次の上らな個人差が山た：

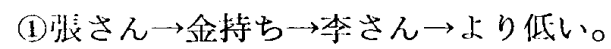

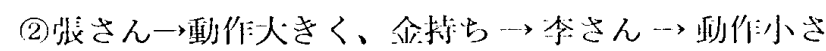
く、金持ら。

2. 意味内容が音声語と、蛽なっている埸合がある。 例之ば、「奇怪」（招かしい）の手諨沉は（ふしぎ、へ んだ）といらような意味もあるし(こっけい）よ゙の您

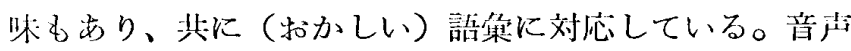
衙の（招かしい）には（いぶかしい）と（こっけい）と いう2つの意味老含まれているが、双方に適刑できる （抢かしい）の手話がない。宕し文中に（招かしい）之 いう唯がある場合（ふしぎ、へんだ）の手都を用いるべ きか、或いは(こっけい)の丁衙を川いるべきを分で

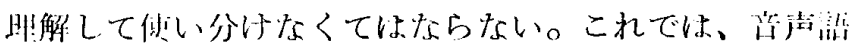

との併用が必要になる。

3. 助詞、助動詞、接続詞、代名詞、敬語、抽象名詞 人名、地名、特有名詞などの手話が少ない。これは台浮

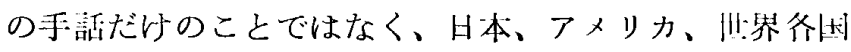
の手話にも其迫点が見られる。

4. 口語との併用を前提として作られていない：読澁 を侀用与るとさ、日を隠したり、日の前を手が移動与る 于語が相当ある。とくに、ある点の手話記号は動作が多 いため、スピーチとの間が时間的にずれることがある。 いくつかの手話を説明的に組み合わせてある棓を表わす

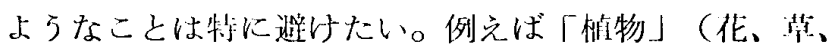
本、色々)。

5. 動作のしにくいすの、見分けにくいものがある： 例光ば（活い）と（旧い）は見分けにくいし、数の八 と「九」の区分は表現しにくい。

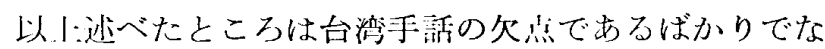
く、アメリカ、日本の手活化笨属な点が少なくない。

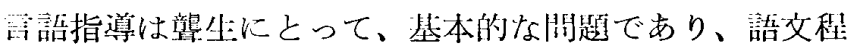

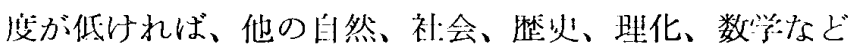

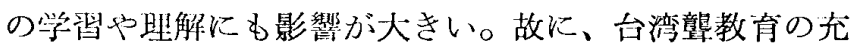
笑を蝹るためには、まず教育力法の拔本的な改善から始

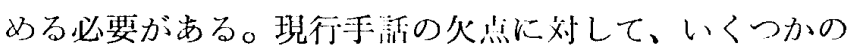
败善意見を提起したい：

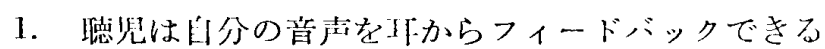
ので、それによって、他人の発語を悦做し、発音や棈文 などを学留するが、㲔児にはそれができにくい。だから、 フィードバックが十分可能な手話法に上って、フィード バック情報の不足を補なってゆく。

2. 暗児の発語は不明瞭なため、どちらか分からない 埸合が多い。例えば「大学」を（Tá Shuéi）と読をか (Lá Shuéi) と読むかは読語では分からない。このよ らなとき、音腤棈造の表現、非解を指文字で確策なるの とする。

3. 手指治注語顺、語の意味内容、付属語などを、中 同語の構造に即した形式で月いるょうに与る。語の配列 が中国語と矛盾していたり、付属媔が双けたりするよう な川いうは避けたい。

4. ヨミュニケーションの目的、艾換し专う情報の显: や内容、受倍㳻、発信者の能力などの現塨の状況に応じ て、他のク法と併用して、效果を高めて、できるだけ、

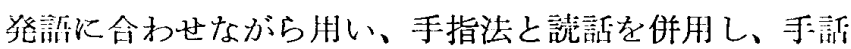
の意味を一既確かにする必要がある。常時、手㨽法を俅 川リ少る必要はなく、若し読話、発語だけで充分コミュー

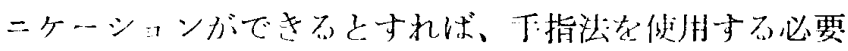
はない。 
5. 手指法は読話との併用を前提とするものであるか ら読詀の妨げにならないよう、口を隠さず、しかもなる ベくロから近いところで行なうことが望ましい。

6. ある手指法の意味がある音声語の一部の意味を合 んでいるというようなことは望ましい形ではない。この 場合は 1 つの音声語に対して、2つ以上の手指法が必要 となる。こういう語が多くなると、手指法の情献量は音 声語以上に大きくなり、手話が音声壀を説明するような 倾向が屾てくる可能性が大きい。

7.ある音声語の意味が広い場合には、意味内容企部 を象微化するような形を考えることは極めて難かしい。 その場合、音声語の音声そのものを手指法化して意味 全体を示寸方式をとるのも一つの方式である。例えば 「等々」(など）の手話は「いろいろ」と同じである が、「いるいろ」だけの手話法としては都合が琹いとこ

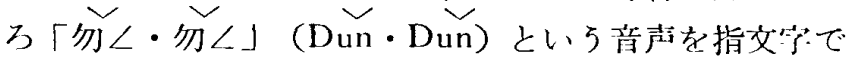
㘳わす。

中国語の三-十七音符の指交等は中国清朝末期（九十・情: 紀後藮）に「只利字母」というものが現われ「黄河流

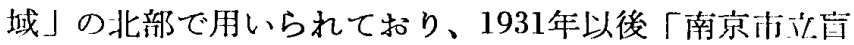
唡学校」で発音符号の指話として使用されていた。第二 次大戦後、台湾の台北冝龍学校が大陸から6名の教䢹を 推聘したが、その一人の方冰美氏がこの発音符号手勢四 を在刻して、教材として教えた。しかし效果があまりに がらなかったので、目めてしまった。その後、今冰美氏 の父、方洪疇氏もこの三十七音符号に基ついて、㲔生の 発省教材を編集して、1、2 年生の壟児に教えた。しか し 3 年生に進むと、やはり手ま权をしてしま5ので、㭪

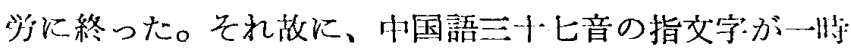
誠みとして使われたが、効果を得られないまっになって いる。

8. ある手話の棓を他の語の組み含せで作ることは発 活との作用、動俳の経済性という面から望ましくない。 例之ば「動物」という単独の手話が日本の手話にないの で「獣十鳥十虫十色々」の手話の複合体になっている が、これは望ましいものではない。これに刘して、台湾 のこの種手話の示しうは単純化している。

9. 例えば「前」という音声語には「場所としての 「前」と「時閒としての前」の雨方の意味が含まれてい る。手指法の「前」には「時間としての前」しか含んで いない。これは原則から言って、歓迎すべさことではな いが、(きの5)、(おととい)、(むかし)などの話に 网連があり、変えにくい。そこで、この手指法に「場所 の闬」に先ずその昜所のサインを示し、そしてその場所

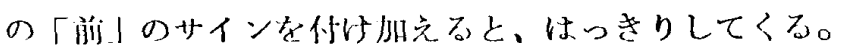

10. 同じ手指法記号を用い、かつ意味の異なるものは 類義語として、文句の中に列挙して示す。例觉ば「春」 「秋」、「跡しい」「暖かい」などの手話は同じであるが 名詞とか、形容詞とかは見分㤝にくいので、文句の巾で 説明すればよいと思う。

\section{6. 現在の台湾における篮教育の問題点}

台湾の意教育を充実させるためには教育方法の面から 改善すべきは勿諭であるが、すべての襲教育に関する対 策、例之ば法令、経費、教育内容、教員養成、教育技 術、施設の措置、育成医療、進路指導、襲者の発生防 川:、社会人の熊度などあらゆる仍度からの改善も必要で ある。以下今後の改善策について意見をまとめてみた Wo

(1) 閌 題 点:

1. 意教育力法に最も重要な教育施設の不完催。

2. 専門訓練を受けた教員が少ない。

3. 驡学校・難聴学級、教室の不足。

4. 親達の理解と協力の不足。

5.中国語における標準語と厅言の不一致。

6. 人口の激增に上る就学特殊児童の膨脹に教育施 設と教員の補充に要する財源が追いつけず、完金な教 夺体制や管理機構も確比ていない。

7. 学級編成が大きすぎる。

8. 卒業生の就職保障が不卜分である。

(2) 改 着 筑:

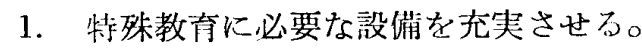

2. 聴能訓練、音感教育を強化する。

3. 龍学校、難聴学級、家庭学級を增設与る。

4. 特殊教育に関する法令を制定する。

5. 特殊学校のカリキュラムや教科書を制定する。

6. 特殊教育関係の経費、狋算を增加与る。

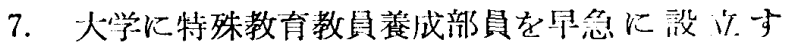
ㄱo

8. 親や社:会人の驡者に対与る偏胃を改める。

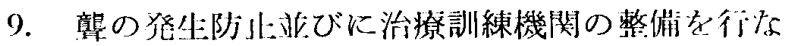
万。

10. 卒菜生の就職斡旋の道を開く。

将来台湾の襲教育がどう進さかという問題について は、驡学校と難聴学級の協力で解決しなければならない と考える。今後、聴覚障害児の教育は幼児期に早く発昌 し、進洰な補聴器を着用させ、普通学級や、特殊学級で 言梁の泉の中に浸らせ、生きた言葉を耳から聞かせて、 付然にしゃべらせるようなう的に進み、教育・医兴・機

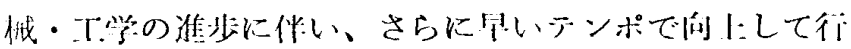


くものと見られ、一分、重度の難㯖児と全㛺児の教育に ついても龍学校で良い䍀境、設備、教育内容、教育方 法、教職員などが整䚚されるといった方向に進さのでは ないかと考兄られる。

\section{7. 結 論:}

以上フメリカ、日本及び台湾の襲教育の变遷と発展の 歴史を操究した絬果、3 国における言語指導法の变遷は いずれも手指法から併用法を経て、口話法移行してい る事実を知った。1880年イタリアのミラノで開かれた競 教育国際会議以来、94年間各国ひとしく口話教青の段階 に向って前進したが、近年来口話教育の技術酒に扣ける 造詣はすで顸点に達した。口話教育方法が大きく進步 乙教具、設储が西期的な革新を経たとしても、竞児教育 の水潐はやはり普通児とのそれと対応できない状態にあ る。各国の心理学者、教育学者はこの壁を打ち破るため に、復古的な考えから、再び手話法の研究実験を行な い、手話法を再評価する傾向にある。いくつかの研究調 査では、手活法が㛺児の読話と発音訓練を妨害せず、か えって知能と社会適応性を高めると認め、語鲰の認識力 を強化させつつあると報告している。故に、私の結論は 「どんな教育力法にも事実上それぞれ其通的に長短得头 があるため、手話法の完全廃止は不叮能であり、また廃 止する必要もない。ただ襲教育に従事する教師達が、授 業を受ける壟児に対して、彼らの知力、程度、個人差、 ニード及び社会環境にマッチした谷種の教育污法を適度 に運用する共汇、各法それぞれの長所を発揮させ、教育 能率を一風高めて行くべきである」といらことである。

$$
\text { (49. 7. } 30 \text { 受) }
$$

\section{参考 交 献}

1. Irene R. Ewing and A. W. G. Ewing : Ewing Speech and the Deaf Child. 1954

2. Report of the Royal Commission on the Blind, the Deaf and Dumb of the United Kingdom, 1889

3. J. Schuyler Long: The Sign Language 1918

4. C. J. Springer, C.SS. R. : Talking with the Deaf 1963

5. Louie J. Fant, Jr.: Say It with Hands 1964

6. Lottie Riekehof : Talk to the Deaf 1963

7. Myrthel S. Nelson: The Evolutionary Process of Methods of Teaching Language to Deaf with a Survey of the Methods Now Employed.
8. The Teacher of the Deaf 1967 March

9. The Teacher of the Deaf 1967 July

10. The Teacher of the Deaf 1896 April

11. Haary Best : Deafness and the Deaf on the United States 1943

12. Anne Davis: The Language of Signs 1966

13. Barker, Roger G. in collaboration with wright, Beatrice A. Myerson Lee, and Gonick R., in "Social Science Research Council Bulletin 55": Adjustment to Plyy. sical Handicap and Illness; A Survey of the Sooial psychology of Physique and Disability 1953, N. Y.

14. Stevenson, Elwool A.: A Study of the Educational Achievement of Deaf Children of Deaf Parent: in "The California News," Vol. 80, 1964

15. Brill, Richard G.: A Study in Adjustment of Three Groups of Deaf Children; in "Exceptional Children," 1960

16. Quigley, Stephen P. and Frisina D. Robert: Institutionalization and Psycho-Educational Development of Deaf Children; in "Council For Exceptional Children Research Monograph," Series A. No.3, 1901

17. Dicarlo, Louis M.: The Deaf. 1964, PrinceHall Englewool Cliffs, N.J.

18. American Annals of the Deaf 1869

19. American Annals of the Deaf 1872

20. American Ahhals of the Deaf 1887

21. American Annals of the Deaf 1896

22. American Annals of the Deaf 1904

23. American Annals of the Deaf 1905

24. American Annals of the Deaf 1920

25. American Annals of the Deaf 1923

26. American Annals of the Deaf 1926

27. American Annals of the Deaf 1929

28. American Annals of the Deaf 1938

29. American Annals of the Deaf 1939

30. American Annals of the Deaf 1940

31. American Annals of the Deaf 1951

32. American Annals of the Deaf 1954

33. American Annals of the Deaf 1961

34. American Annals of the Deaf 1963

35. American Annals of the Deaf 1964 
36. American Annals of the Deaf 1966

37. American Annals of the Deaf 1968

38. American Annals of the Deaf 1969

39. 川本宇之介著「襲教育谷精説」光文社 昭和 15年.

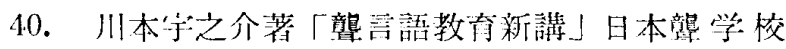
校会発行, 昭和29年.

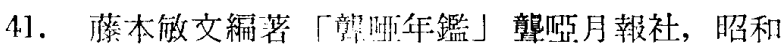
10年.

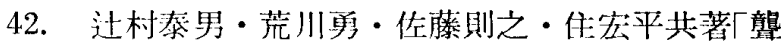
教育史」日本特殊教育協会発行, 昭和 42 年.

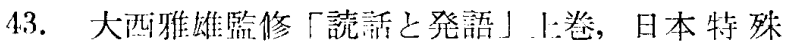
教育協会発行, 弨和44年.

44. 大川倠即 - 过村泰男 - 寒川英希 -中川秀夫。 作实平・三木安正 編集「特殊教育事典」第一 法規，昭和143年.

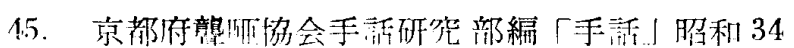
年.

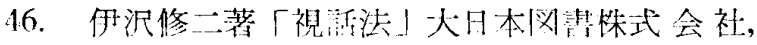
明治34年.

47. Wilhelm Wundt 著，此屋根安定补「民族心 理学! 誠信書屡，昭和34年.

48. 霞觉勝著「手の心理」牧書局，睢和30年

49. 松永端著「手活辞典」日本特殊教育協会，昭 和38年.

50. 松永端著「手京初入門」日本特殊教育協会, 昭和39年.

51. 剑木義夫著「休部術でこんにらは」,ーベル 書联，燳和44年:

52. 早橓田大学教育心理学破究空龍心理研究 会 編 「月本手訢図絵!1963年９月。

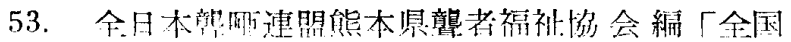

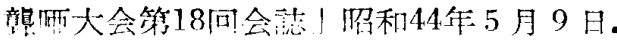

54. 難聴巟を持つ親の会編「難:聴」Vol.4，昭和 44华 5 月。

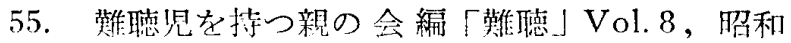
44年6月。

56. 「難聴」Vol.9，昭和 44年11月.

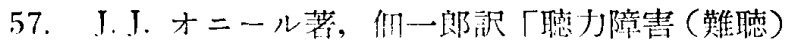
日本交化科兴社，1968年.

58. 部教育科学会編「ろ 万教育科学」第 9 巻第 3 号，1967年11月。

59. 部教育科学全䋧「万5教育科学」第 10 巻第 1 号，1968年 5 月。
60. Samual A. Kirk 著, 伊藤隆二訳「特殊教育 入門」昭和 44 年.

61. D. G. Pritchard 著, 岩本憲監訳「障害児教 育の発澾」昭利44年.

62. 栃木県立龍学校, 栃木県龍㖶協会 編「手話法 辞典」炤和44年。

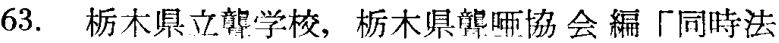
について」1969年10月 1 日.

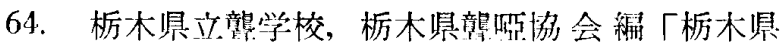

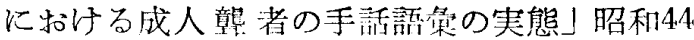
年.

65. 一番ケ瀬康子著「アメリカ社会福祉発達串」 光生館，昭和38年.

66. 樋口長方著「小酉信八先生存稿集」光文社, 昭和10年.

67. 中野善迲・加櫒康炤共著「わが国特殊教育の 成文」東峰書呞，眧和42年

68. 文部省調查普及局編「わが国及び齐同の特殊 教育」刀汇畫局，眧年24年.

69. 文部省綜「わが国の特殊教育」大日本印刷株 式会社，昭和36年.

70. 宮瀬㓐夫著「一般教弆科兴」大村書局，昭和 38年.

71。 木由微郎著「社会福礼事業」川島䓢局，昭和 42年.

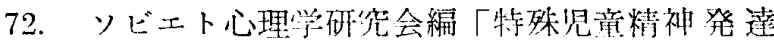
の諸閂題」1966年.

73. 汸古尚三著「台湾に招忛教育上の諸問題」 拓列大学海外事情研究所編「海外事情」特集 「台湾」1967年3月号.

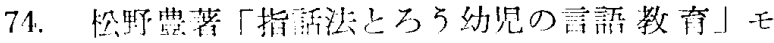
ノジラフ，1962年

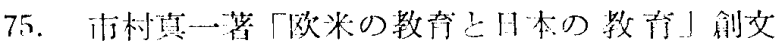
礼，眧和39年.

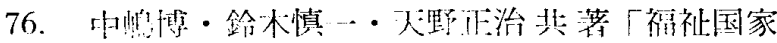

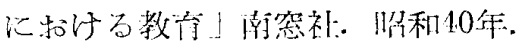

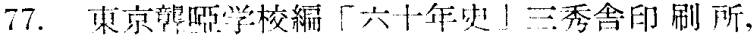
埳和10年。

78. 堀口伸作・何田忠信共都「万弓その他の恥覚 浯平衡機能障㫮のリハビリテーション! 1965年.

79. 任田忠信著「小児の難蚛とその最近の問題」 国立聴力言語㜔害センター，1968年.

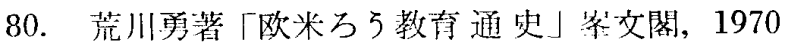
年. 


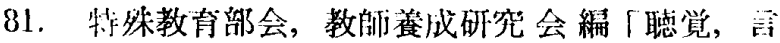
话i障害児教育」学芸図畫株式会社，1972年.

82. 人川原潔等共編「特殊教育用語 辞典」第一法 䙺论版社，昭和44年.

83. 任:滕則之監修「言語指導用势解説」日本汹㫪 文化協会，1974年4月20日.

34. 聴覚障害者教育福祕協会編「ひびき」Vol. 11

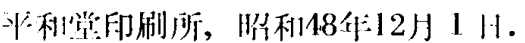

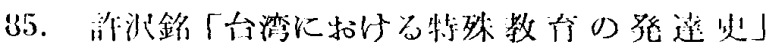
1968作 1 小。

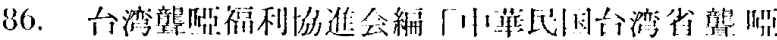
福利協進会成立 7 周年紀念特刊」

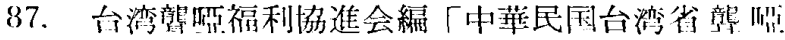
䘞利協進会成汒10祘年紀念殊刊」

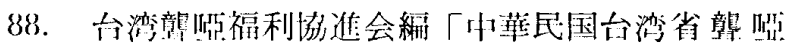
福利協進会成立12周年紀念特刊」

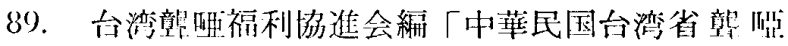
福利協進会成立13周年紀念特刊」

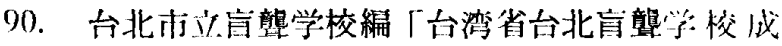
文.20周年校慶特刊」1966年.

91. 台湾省政府教育庁 編「台湾省教育統訫」1969 作.

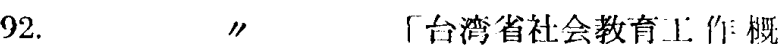
沉」 1959禾:

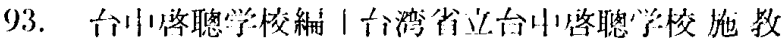
們介説明」1969年:

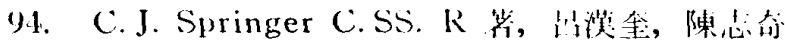

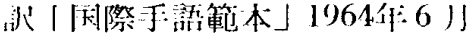

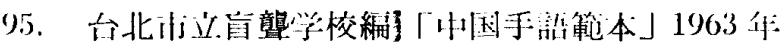
5 月.

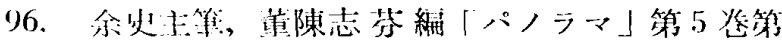
1 号，1968年 1 月.

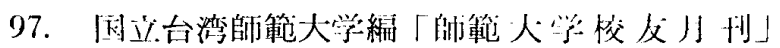
Vol. 77，1969年10月20日.

98. 佐藤親雄著陳天甜 - 余鶴清䚿「特異思童教台 的認識」台湾啓聰学校, 1968年:

(1974.7.30 罠) 


\title{
A STUDY ON THE INSTRUCTION OF LANGUAGE FOR THE DEAF CHILDREN - FOCUSED ON THE MANUAL MEDIUM METHOD OF AMERICA, JAPAN, AND TAIWAN, R. O. C.-
}

\author{
HOKI RIN
}

\section{MOTIVATION :}

The development of special education of the progressive countries has been very great. Unlike Taiwan, their language teaching in the education for the deaf has also been developed in those scientific methods of oral, lip-reading, speech-reading and hearing, therefore it is of great necessity that we have to study the conditions of the progressive countries.

Though Japan and America began their education for the deaf much later than some European countries, yet they have had many outstanding effects. Therefore, in order to improve the education for the deaf in Taiwan, I would study the language teaching of these two countries.

To the deaf, the manual communication is their native language, no matter how oral method is improved, we still should not and could not neglect or give up the manual communication method.

Those countries, such as Japan, America, Russia, Denmark and England have recently paid great attention to the sign and manual system. In a lot of researches and experiments they reported that the manual method (including fingerspelling) doesn' $t$ hinder the oral and speech training of the young deaf children. And the widelyknown oral method which has been the most popular method in the deaf education for nearly a century should be re-evaluated.
Besides, it is necessary for the teachers of the deaf in Taiwan who have yet taught mainly in manual method to have a real recognization of the existing condition of the practical manual method. Therefore this study is mainly centered on comparing and analyzing the practictical manual method based on America, Japan, and Taiwan.

\section{PROCEDURE :}

First to study the literature of the establishment and changing of the education for the deaf in America, Japan, and Taiwan. Next to compare and analyze every kind of language instructions, (manual method, oral method, combined method, etc.) and see what advantages or disadvantages they resulted. Then to compare the manual communication method in America, Japan and Taiwan (As to their method I will explain in photoes.). And the last, to inspect the education for the deaf in Taiwan and see the way to improve it.

\section{SUMMARY :}

This study is made up of five chapters. In the first chapter, the establishment and the background of the organizations established of the education for the deaf of Europe, America, Japan, and Taiwan are introduced. Chapter two is the comparison and analysis on the theory of all the communicative methods. Chapter three is the 
analysis of sign language instruction and its practicality of education in America, Japan, and Taiwan. Chapter four is the comparison of signs in America, Japan and Taiwan with illustrations. The last chapter is the examination of the status quo of the education for the deaf in Taiwan, and the ways to improve it.

\section{CONCLUSION :}

With a study of the changing and development of the education for the deaf in America, Japan and Taiwan, I come to understand that the language instruction of these three countries are all developed from manual method to combined method and then to the modern state of oral method. For ninety four years since the international conference in Milan, Italy in 1880 , the most of the countries have come to the stage of oral method in educating the deaf. Yet, no matter how modernalized the teaching equipment is, the standard of the education of the deaf children is unable to equal that of the normal ones. Therefore, we again think that manual method has to be re-evaluated and reviewed.

With a view on the reports of the experiments and researches of those psychologists and educators in Japan, America, England, Russia, Denmark, my conclusion is that "Manual method can obviously help with oral method, esp. in the instructions of those retarded deaf children. Manual method is the deaf's native language, to discard or forbid the use of it is not only impossible but unnecessary.

For under the circumstances when its shortcomings are improved can add to the deaf children's intelligence, vocabularies and their ability of social adjustment." 